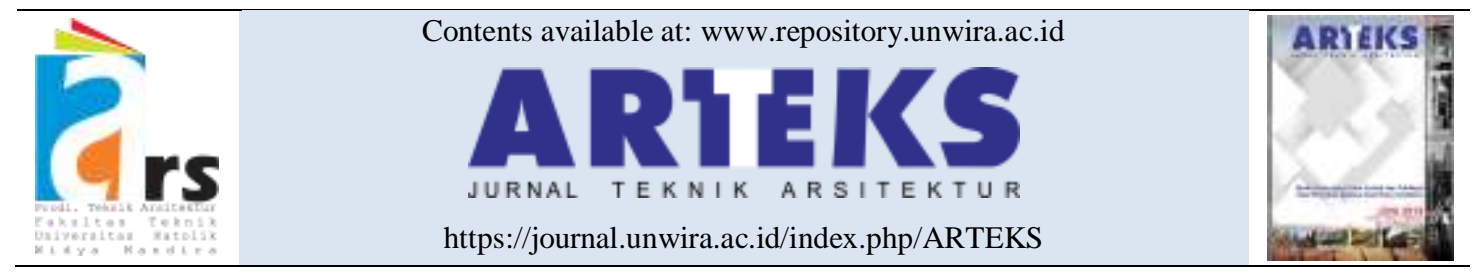

Research paper

doi: $10.30822 /$ arteks.v6i2.755

\title{
Acculturation of local and non-local architecture on the scoping elements of the Merah Panjunan Mosque building in Cirebon
}

\author{
Arita, Hartanto Budiyuwono* ${ }^{\circ}$, Yuswadi Saliya \\ Master of Architecture Study Program, Faculty of Engineering, \\ Universitas Katolik Parahyangan \\ Jl. Ciumbuleuit no. 94, Bandung, Indonesia
}

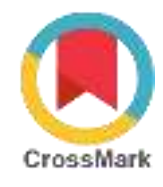

\begin{tabular}{|c|c|}
\hline ARTICLE INFO & BSTRACT \\
\hline $\begin{array}{l}\text { Article history: } \\
\text { Received November } 29,2020 \\
\text { Received in revised form Dec. 06, } 2020 \\
\text { Accepted December } 14,2020 \\
\text { Available online August } 01,2021\end{array}$ & $\begin{array}{l}\text { Architectural acculturation has a significant and uniform impact on } \\
\text { modern architecture. However, the misunderstanding of this } \\
\text { phenomenon tends to occur due to its inability to match its context's } \\
\text { function and meaning. Therefore, this study aims to examine the } \\
\text { acculturation of local and non-local architecture in mosque }\end{array}$ \\
\hline $\begin{array}{l}\text { *Corresponding author: Hartanto } \\
\text { Budiyuwono } \\
\text { Department of Architecture, Faculty of } \\
\text { Engineering, Universitas Parahyangan, } \\
\text { Indonesia } \\
\text { Email: budi222002@yahoo.com } \\
\text { ORCID: https://orcid.org/0000-0003-0484- } \\
0894\end{array}$ & $\begin{array}{l}\text { buildings. Previous research only focuses on mosque buildings as a } \\
\text { syncretic factor, with none on the attributed topic. The research } \\
\text { object is the Merah Panjunan Mosque in Cirebon City. This object } \\
\text { was chosen based on the building age, the acculturation } \\
\text { phenomenon that occurs, and because it is one of the cultural } \\
\text { heritage in Cirebon City. The research method includes redrawing } \\
\text { the Merah Panjunan Mosque's entire mass in three and two } \\
\text { dimensions, making it easy to parse based on architectural anatomy. } \\
\text { The study object's decomposition is intended to facilitate analysis in } \\
\text { each unit of architectural elements, which is read based on the } \\
\text { elaboration of the balance and orientation principles. The analysis } \\
\text { results are interpreted in the conclusion section with the Merah } \\
\text { Panjunan Mosque capable of displaying local and non-local } \\
\text { architecture characterized by Javanese and Chinese architectures } \\
\text { as well as a Hindu temple. The dominant composition of the Merah } \\
\text { Panjunan Mosque acculturation is shown in the roof elements. } \\
\text { Therefore, this research implies that Merah Panjunan acts as a } \\
\text { reference for architectural design with the acculturation concept. }\end{array}$ \\
\hline
\end{tabular}

\section{Introduction}

Generally, acculturation is the concept of combining various styles of historical local culture and elements formed on the outside of a building (Roszi and Mutia 2018). According to Ayuningrum (2019), good acculturation is formed in a building when it represents a balanced mix of immigrant and local culture. However, many acculturation concepts are misapplied due to misunderstandings in mixing certain elements without considering their function and meaning (Purnama Salura 2012; 2013).
The misunderstanding acculturation phenomenon has a significant impact on designing architecture science. The misconception of this phenomenon does not copy the decoration of local architectural elements; therefore, architects find it difficult to understand the techniques used to transform and synthesize local potentials (Lake et al. 2020). In Indonesia, the dominant concept of architectural acculturation occurs in various forms of buildings. In 1980, the government proclaimed the development concept of archipelago architectural identity in offices and educational buildings (Ismail 1989; Sopandi 2009; 2017; Lake 
et al. 2020). The current development of modern architecture increased the importance of acculturation studies. Furthermore, the acculturation concept is one of the efforts used to maintain local identity values (Messakh 2014).

Similarly, acculturation studies dominate the syncretism concept used to build mosques, which is influenced by the meanings of religious beliefs or streams (Ashadi, Antariksa, and Salura 2015).

The mosque is an architectural building full of doctrine without reference to its physical form and order (Paramitha and Salura 2020). Its shape is similar to office buildings and museums; therefore, it tends to act as a means of cultural development (Fanani 2009; Purnama Salura and Clarissa 2018). Cirebon consists of several mosques with Chinese architectural features (Siswoyo, Nuryanto, and Mardiana 2019; Pepeh 2020).

Numerous studies have been carried out on mosque architecture, which is dominated by syncretism issues (Ashadi, Antariksa, and Salura 2015; Purnama Salura and Clarissa 2018; Jamaludin and Salura 2018). However, studies related to local and non-local architectural acculturation of mosques are scarce. It is important to study the acculturation of non-local architectural elements of mosques in Cirebon because they all have the characteristics of Chinese architectural styles and temples. Therefore, the purpose of this study is to explore and examine the architectural acculturation in a mosque. This research specifically explores the acculturation of local and non-local architectural elements in the Merah Panjunan Mosque in Cirebon.

This research is useful due to numerous reasons. Firstly, it is used to explain how the acculturation process occurred between local and non-local architecture in the oldest mosque in Cirebon academically. Secondly, it fills in the vocabulary for the acculturation concept of mosque architecture, which is rare. Thirdly, it contributes to the mosque's acculturation concept as an architectural design, and fourthly, it acts as a reference for further study of mosque architecture.

\section{Method}

Data were obtained from Merah Panjunan Mosque located in Cirebon City, Kolektoran street, Panjunan Village, Lemah Wudul subDistrict, West Java Province (Gunawan 2013). The geographic coordinates of the Merah Penjunan Mosque are $6^{\circ} 43^{\prime} 3.16^{\prime \prime} \mathrm{S}$; $108^{\circ} 33^{\prime}$ 57.71" E, as shown in figure 1 (Gunawan 2013). The Merah Panjunan Mosque, which was initially known as al-Athyah" meaning "the beloved," was founded by Syarif Abdurrahman in 1480 (Wijaya 2008). This mosque also acts as evidence of the Arab descendants' migration to Cirebon in the 14th century (Hermana 2012).

The mass area of the building is $150 \mathrm{~m}^{2}$, as shown in figure 2 . The slice, building view, and three dimensions of the mosque are shown in figures 3, 4, and 5. Furthermore, the mosque was named Merah Panjunan because it is built of red bricks and also refers to the village where it was built. The mass complex of the Merah Panjunan Mosque is enclosed by a red brick fence arranged to resemble a temple. The main entrance is built by a pair of Bentar temples equipped with carved teak panel doors, as shown in figure 6 .

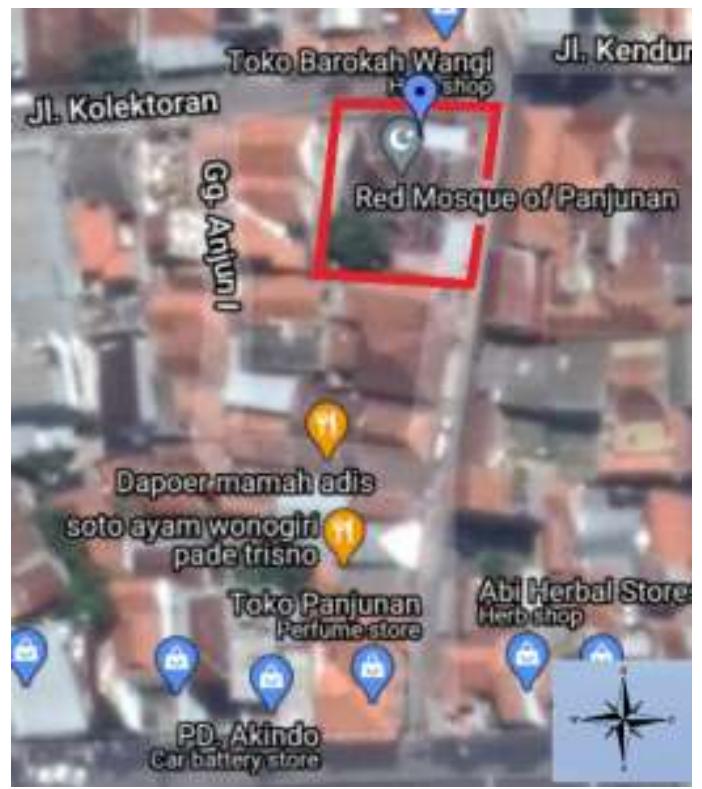

(a) 


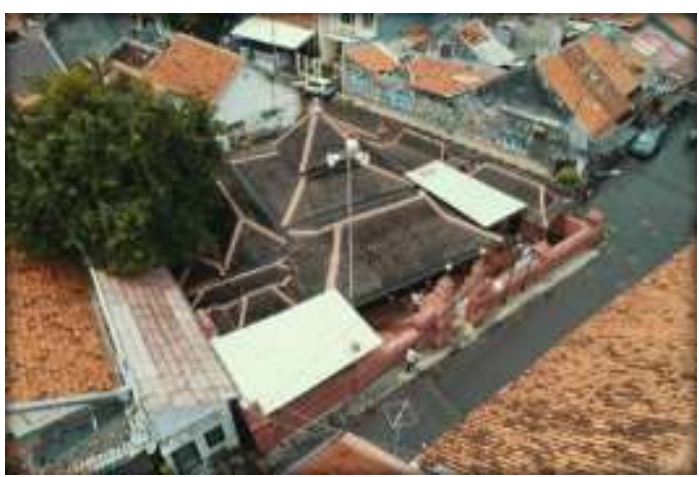

(b)

Figure 1. (a) Map; (b) Site Merah Panjunan Mosque Location in Cirebon City

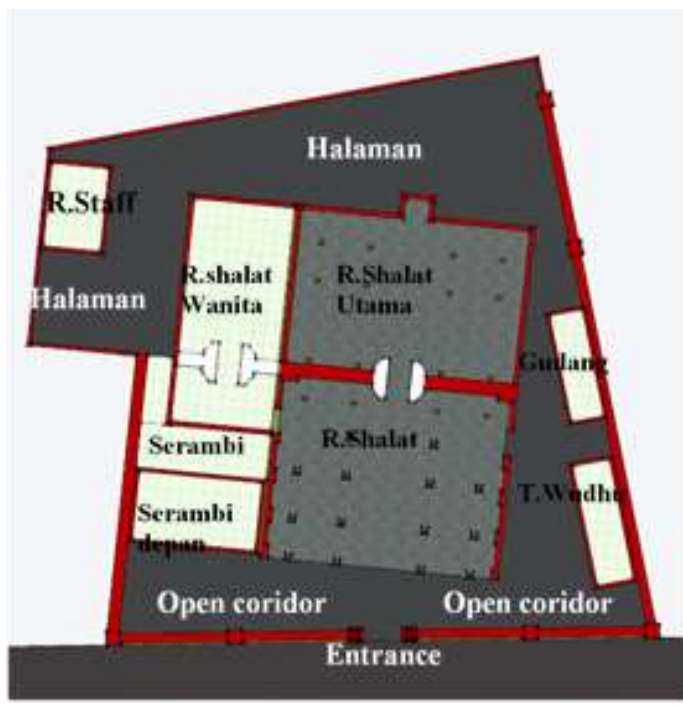

Figure 2. Merah Panjunan Mosque plans
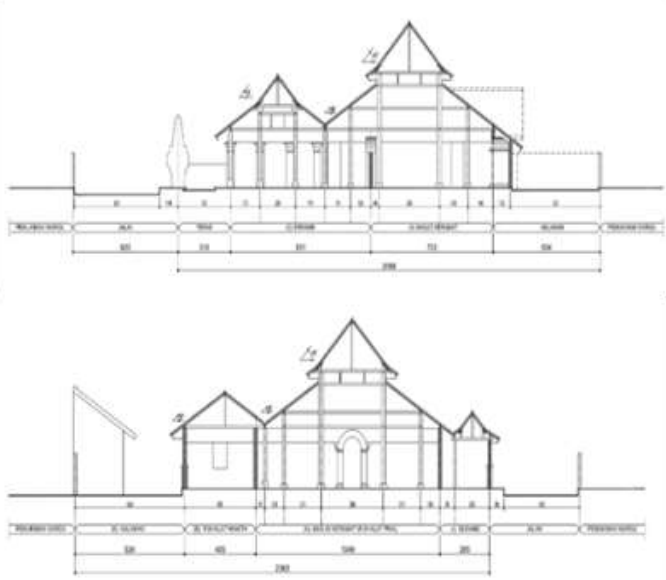

Figure 3. Pieces of the Merah Panjunan Mosque building mass

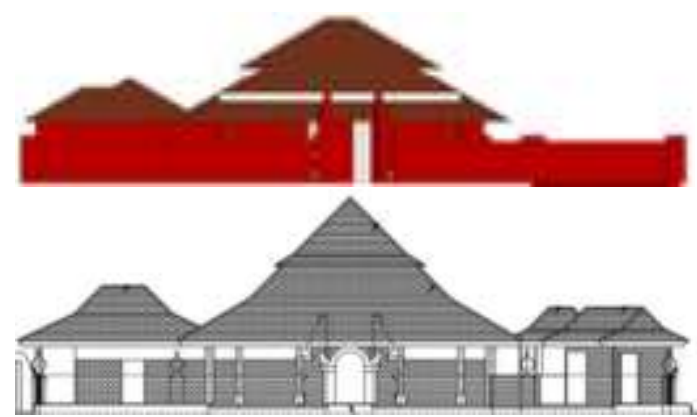

Figure 4. Front view of the Merah Panjunan Mosque building mass

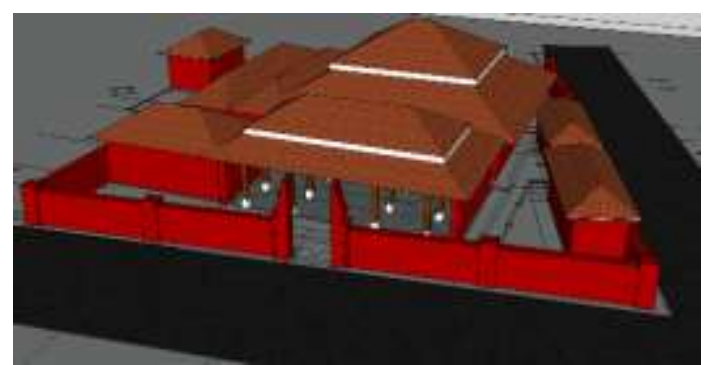

Figure 5. Three dimensions of the Merah Panjunan Mosque building mass

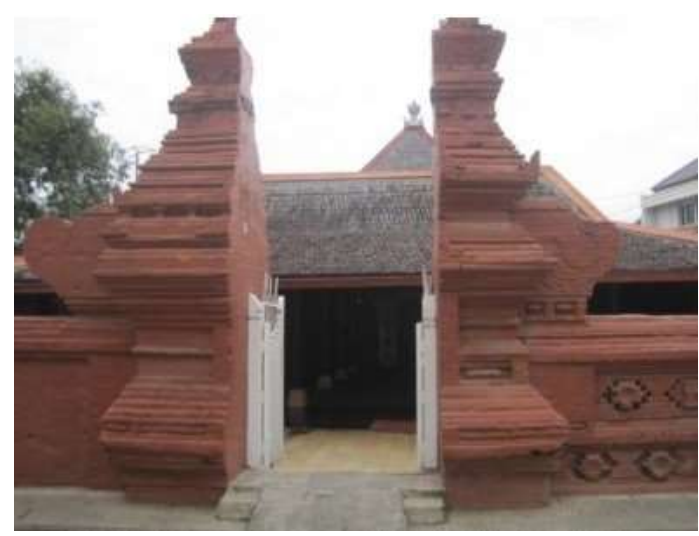

Figure 6. The main entrance to the Merah Panjunan Mosque complex in Cirebon City was built as a pair of Bentar temples

The criteria for determining the case study were based on the oldest mosque architecture (Wijaya 2008; Gunawan 2013), which includes conservation buildings in Cirebon based on Ministerial Decree No. PM.58 / PW.007 / MKP / 2010 (Ditjen Kemendikbud 2010). Secondly, the buildings were based on mosques with dominant characteristics of Chinese and local architectural elements (Znews 2020). Finally, it was based on buildings that function properly. In carrying out the research steps, firstly, the entire case study was re-recorded in the form of two and 
threedimensional images. This allowed for easy examination and break down. The results of describing the case study were then analyzed in part based on architectural anatomy theory $(\mathrm{P}$ Salura 2018) and structuring principles (Purnama Salura 2001; 2010; 2018). The basis of architectural anatomy theory is carried out by categorizing the building as an anatomical analysis unit to facilitate the search for the elements' shape and material acculturation.

Secondly, the structuring principles theory was used to read the non-local and local architecture characteristics in each architectural anatomy of the building. The second step was carried out to trace the acculturation that occurs in the elements covering the Merah Panjunan Mosque architecture in Cirebon.

Thirdly, in-depth interviews were conducted to determine the architectural style. Fourthly, the results were interpreted to determine the dominant elements.

\section{Result and discussion}

Interpretation of Merah Panjunan Mosque building principles

The entire elements that make up the Merah Panjunan Mosque building are based on the balance and orientation principle. The balance principle creates a relation between the part and the whole, which consists of axes, fastening, repetition, and rhythm. The orientation principle consists of the top-down, front-back, and far-near hierarchy principles.

Therefore, based on the balance and orientation principles, the substance and characteristics of the Merah Panjunan Mosque building elements are interpreted as follows.

1) Analysis of balance principle

a. Axis: The Merah Panjunan Mosque consists of elements related to the vertical axis. This is also dominated by a towering roof on the mosque's main building, which is a combination of the pyramid shape of Hindu temples, jurai arches of Chinese architecture, and the composition of two roofs piled as a Javanese architecture. The mosque's horizontal axis is limited by two building masses of the left-right porch, which is separated from the main mosque, as shown in figure 7 .

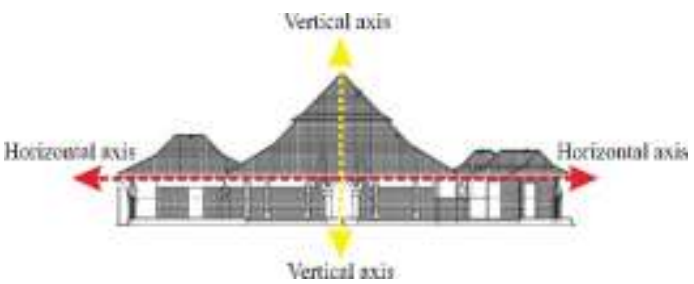

Figure 7. Vertical and horizontal axes on the Merah Panjunan Red Mosque building mass

b. Binder: The two buildings on the left and right axis are bind by a central/main building mass marked by a two-stacked roof and tower, as shown in figure 8 .

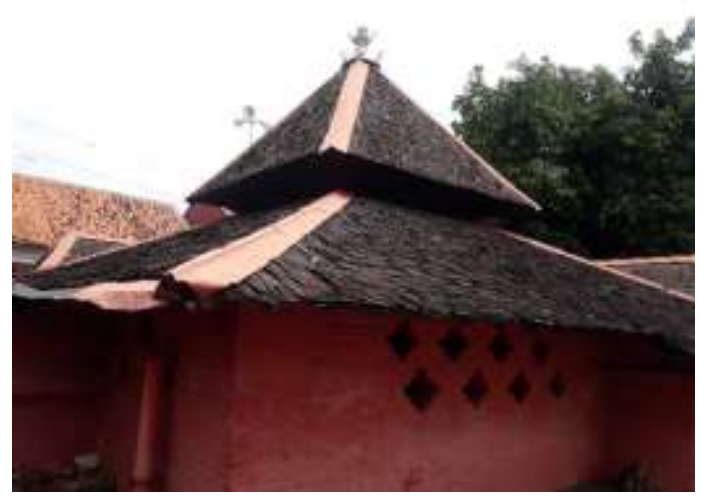

Figure 8. The main building of the Merah Panjunan Mosque with a double roof with a large mass that binds the entire building

c. Rhythmic repetition: The mass repetition area comprises a trapezium roof characterized by Javanese architecture, as shown in figure 9. Furthermore, the repetition of walls building mass with decorative ceramic plates is a Chinese cultural characteristic, as shown in figure 10.

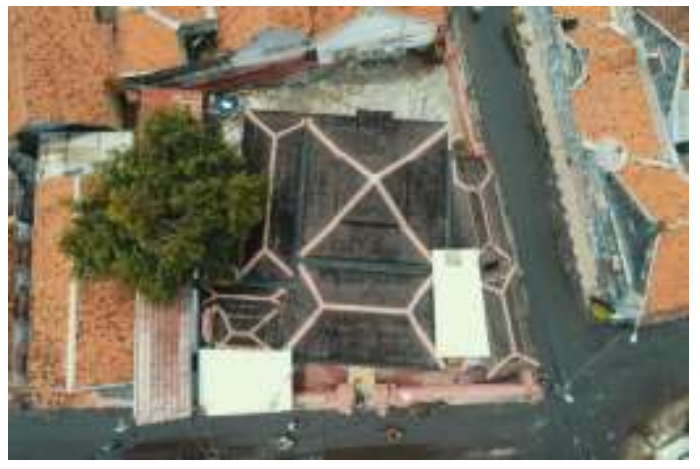




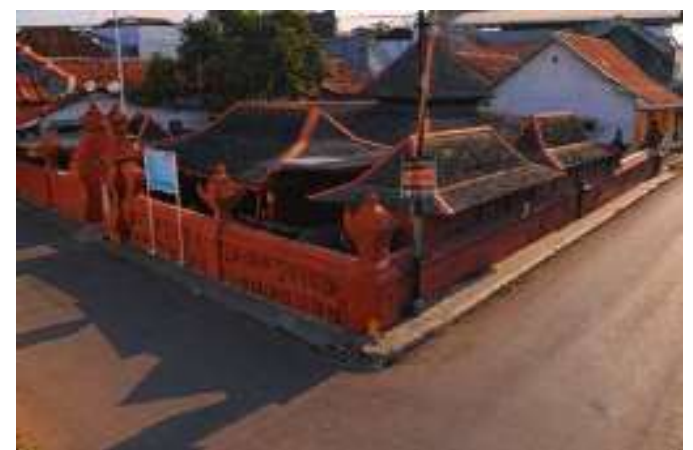

Figure 9. The trapezoidal roof rhythm repetitions characteristic of local Javanese architecture in the Merah Panjunan Mosque
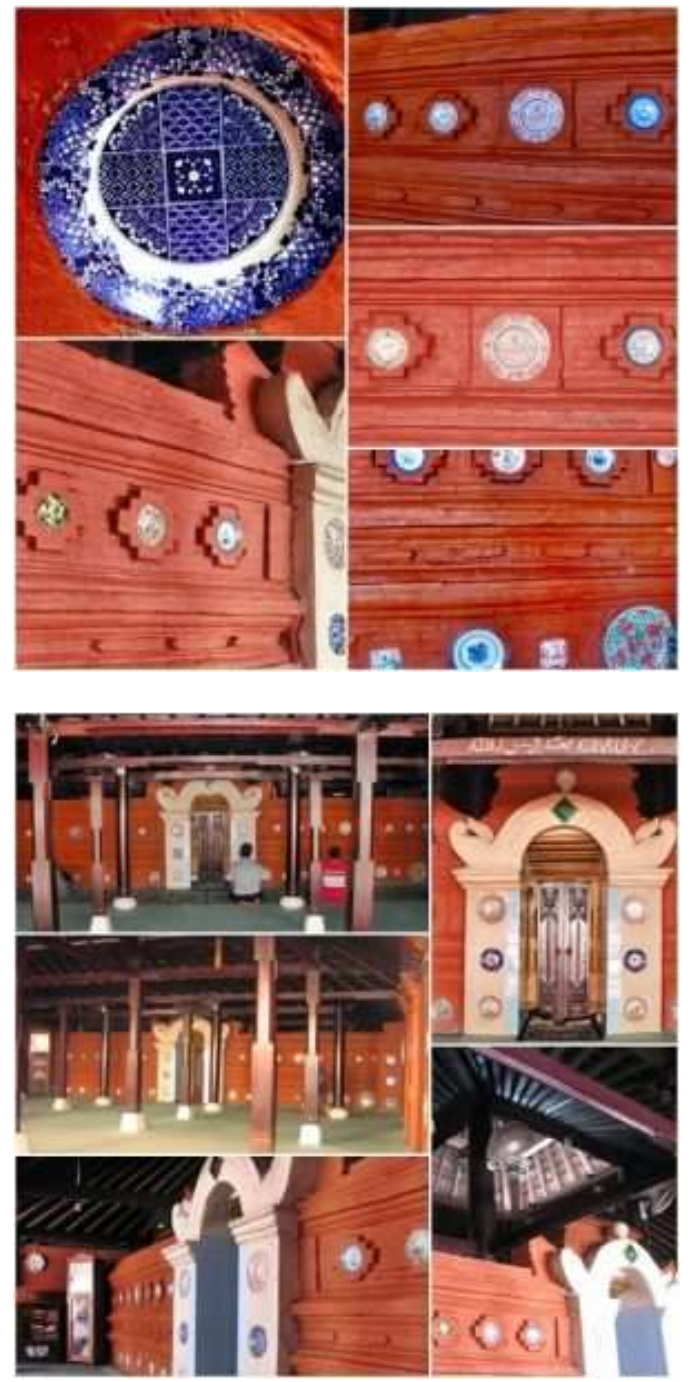

Figure 10. Repetition-rhythms of Chinese culture patterned ceramic plates on the walls of the Merah Panjunan Mosque building

Source: (GPS Indonesia Tourism 2014)
2) Analysis of the orientation principle

Center and left-right: The main mosque located in the middle acts as the overall mass composition. The mosque's main building has a mass size and shape that is larger than others and in the form of a double-decked roof. It is a monumental scale, towering like a Hindu temple with its walls dominated by decorative Chinese plates. The main building mass of the mosque has a higher value than the left and right portions.

Acculturation interpretation of the Merah Panjunan Mosque building

1. Top scoping element (roof)

The Merah Panjunan Mosque consists of two types of roofs. The first is stacked in two with ornaments that are similar to the pyramid shape of Hindu temples. The roof is called a memolo, which means that it resembles a king's crown, as shown in figure 11 . The community believes that the memolo form is a symbol of a king crown with a floral pattern, is adopted from the world of puppetry with life nuances. The roof part of the main building mass is an iconic sign with an index adopted from a Javanese house's trapezium roof.

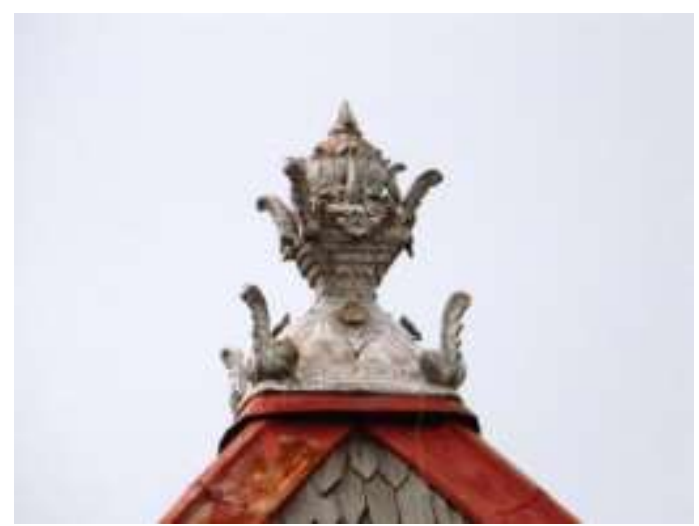

Figure 11. Memolo at the rooftop of the main building of the Merah Panjunan Mosque

2. Middle scoping elements (walls, columns)

The massive red wall with vents openings is a sign of a tropical building, as shown in figure 12 . There are many decorative reliefs of sunflowers and other flora attached to the massive walls resembling religious buildings in the Middle East, as shown in figure 13. Furthermore, the wall decorations are dominated by ceramic plates with Chinese patterns. The plates were a gift from the Chinese emperor to Sunan Gunungjati during a marriage ceremony to Ong Tien's daughter. Another central scoping element in the Merah 
Panjunan Mosque is wooden column poles with Javanese architectural characteristics. There are umpak (rock support) and carving typical Javanese cultural decorations on each column, as shown in figure 14. The column poles shape is rectangular, the structural system and construction of the column poles adopt the soko guru (main support pole), as shown in figure 15.

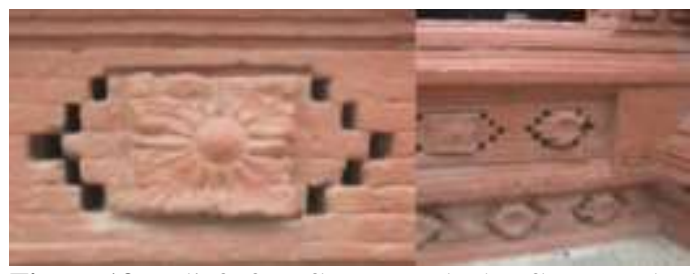

Figure 13. Relief of sunflowers and other flora attached to the wall of the Merah Panjunan Mosque building
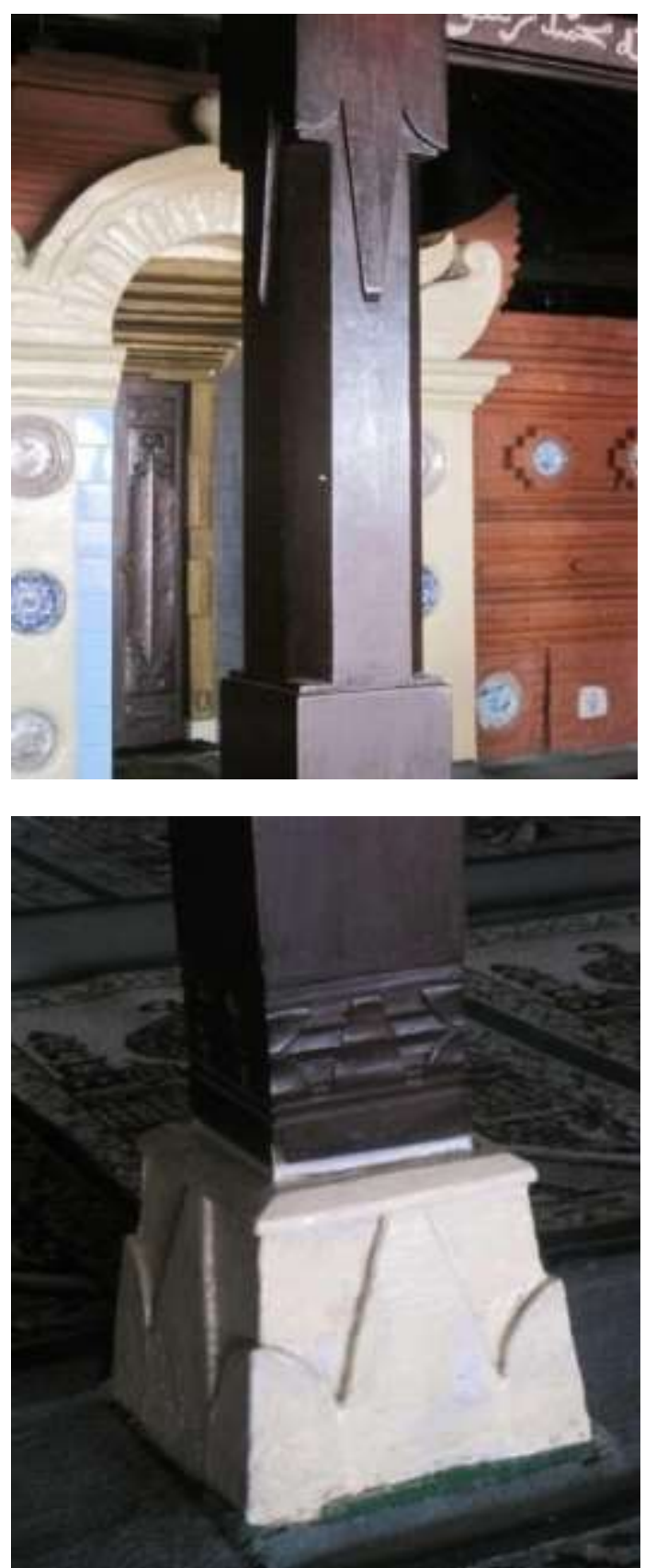

Figure 12. The vent on the wall of the Merah Panjunan Mosque building

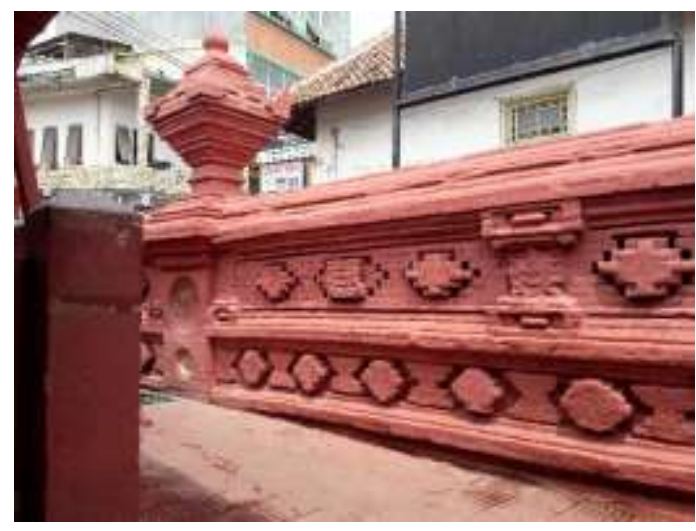




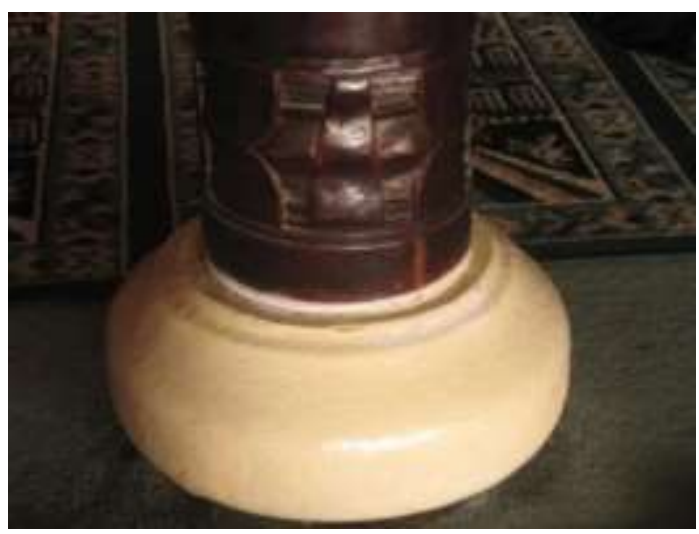

Figure 14. Carvings typical of Javanese culture on each interior column of the Merah Panjunan Mosque building

Source: (GPS Indonesia Tourism 2014)
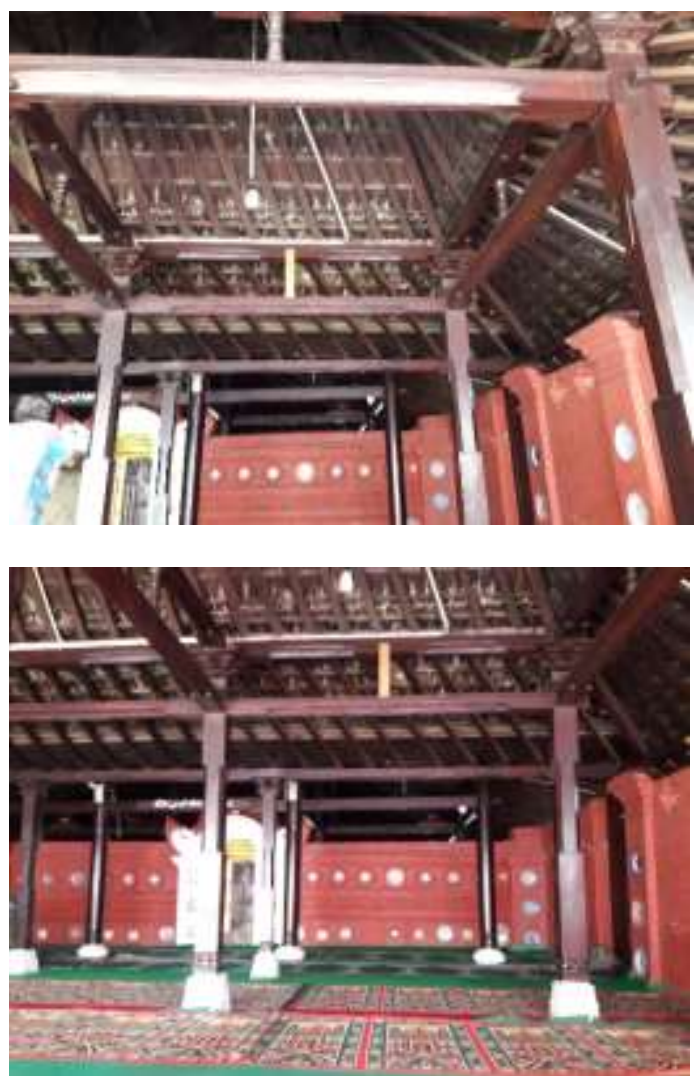

Figure 15. The interior columns' structural and construction system on the Merah Panjunan Mosque building adopts soko guru from Javanese architecture

3. Scoping element of the base (floor)

The base or floor scoping elements of the building express floor elevation pattern, based on the hierarchy of space in the Merah Panjunan Mosque. Furthermore, the high-low floor pattern's hierarchical concept resembles the division of spaces in Hindu temples, as shown in figure 16. The floor material is tiled or colored with plain pattern and red, which is dominant in Chinese architecture, as shown in figure 17.

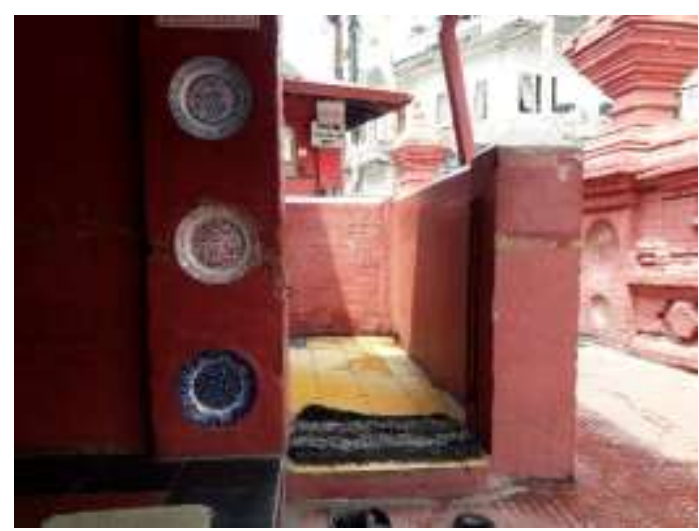

Figure 16. Floor level differences in the Merah Panjunan Mosque building

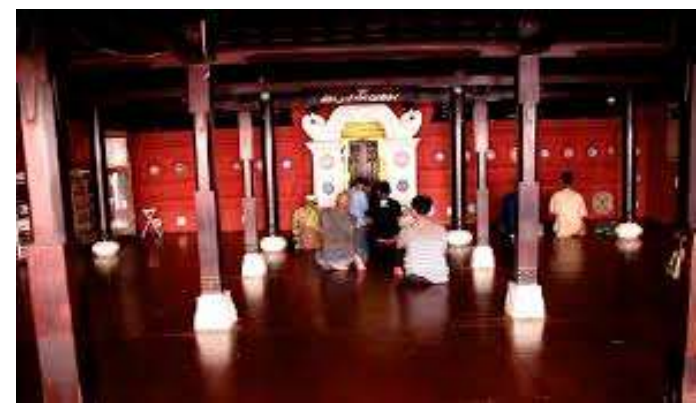

Figure 17. Floor tiles or tiles with plain pattern and red color

\section{Conclusion}

Based on the analysis, it can be concluded that this study puts forward a new method for reading the acculturation of local and non-local architecture in the mosque building analysis unit. Furthermore, the analytical method elaborates balance and orientation principles.

Secondly, the Merah Panjunan Mosque building in Cirebon City displays the synergy of local and non-local architectural acculturation using Javanese and Chinese features. In addition, Hindu architecture also creates a harmonious blend of local and non-local values. The dominance of the Merah Panjunan Mosque building form's overall composition is the element that refers to the two-tiered roof form and the pyramid of Javanese architecture. 
Thirdly, the research reveals that local and non-local architectural acculturation can be used as a reference for architectural design, especially in building mosques. This is because local and non-local architectural elements' acculturation process provides values that have survived Kiwari changes.

\section{References}

Ashadi, Antariksa, and Purnama Salura. 2015. 'Syncretism in Architectural Forms of Demak Grand Mosque'. J. Appl. Environ. Biol. Sci.

Ayuningrum, Diah. 2019. 'Akulturasi Budaya Cina Dan Islam Dalam Arsitektur Tempat Ibadah Di Kota Lasem, Jawa Tengah'. Sabda : Jurnal Kajian Kebudayaan 12 (2): 122. https://doi.org/10.14710/sabda.12.2.122-135.

Ditjen Kemendikbud. 2010. 'Masjid Merah Panjunan’. Sistem Registrasi Nasional Cagar Budaya. 2010. https://cagarbudaya.kemdikbud.go.id/public/ objek/detailcb/PO2014082800004/masjidmerah-panjunan.

Fanani, Achmad. 2009. Arsitektur Masjid. Yogyakarta: Bentang. https://books.google.co.id/books?id=Cs3p7ir 7bk0C\&printsec=copyright\&redir_esc $=y \# v=$ onepage \&q\&f=false.

GPS Wisata Indonesia. 2014. 'Masjid Merah Panjunan Cirebon Jawa Barat'. GPS Wisata Indonesia. 2014. https:/gpswisataindonesia.info/2014/02/masj id-merah-panjunan-cirebon-jawa-barat/.

Gunawan, Hendra. 2013. 'Masjid Merah Panjunan - Cirebon'. Rindu Masjid. 2013. https://bujangmasjid.blogspot.com/2013/05/ masjid-merah-panjunan-cirebon.html.

Hermana. 2012. 'Arsitektur Masjid Merah Panjunan Kota Cirebon'. Patanjala: Jurnal Penelitian Sejarah Dan Budaya 4 (2): 151-67.

Ismail. 1989. Wawasan Jatidiri Dalam Pembangunan Daerah. Semarang.

Jamaludin, J., and Purnama Salura. 2018. 'Understanding the Meaning of Triangular Shape in Mosque Architecture in Indonesia'. International Journal of Engineering \& $\begin{array}{llll}\text { Technology } & 7 & \text { (4.7): } & 458 .\end{array}$ https://doi.org/10.14419/ijet.v7i4.7.27359.

Lake, Reginaldo Christophori, Fransiscus X. Eddy Arinto, Yohanes Djarot Purbadi, Yohanes Basuki Dwisusanto, Elvis Albertus
Bin Toni, and Robertus Mas Rayawulan. 2020. 'Architecture Expression: Synthesized Architectural Expressions in Mayor's Office Building of Kupang City'. Local Wisdom: Jurnal Ilmiah Kajian Kearifan Lokal 12 (2). https://doi.org/10.26905/lw.v12i2.4302.

Messakh, Jeni. 2014. 'Wujud Akulturasi Sebagai Pembentuk Identitas Arsitektur Nusa Tenggara Timur'. E-Journal Graduate Unpar. http://journal.unpar.ac.id/index.php/unpargra duate/article/view/1196/1166.

Paramitha, Nadya Wicitra, and Purnama Salura. 2020. 'Relasi Antara Sakralitas Ritual Peribadatan Berjamaah Dengan Konfigurasi Spasial Arsitektur Masjid Sulthoni Plosokuning'. ARTEKS: Jurnal Teknik $\begin{array}{llll}\text { Arsitektur } & 5 & \text { (2): } & \text { 143-52. }\end{array}$ https://doi.org/10.30822/arteks.v5i2.103.

Pepeh, Udin. 2020. 'Inilah Masjid Merah Panjunan Dari Cirebon Perpaduan Budaya Islam, Cina Dan Hindu'. Inspirasi TV. 2020. https://www.inspira.tv/news/1496/inilahmasjid-merah-panjunan-dari-cirebonperpaduan-budaya-islam-cina-dan-hindu.

Roszi, Jurna, and Mutia. 2018. 'Akulturasi NilaiNilai Budaya Lokal Dan Keagamaan Dan Pengaruhnya Terhadap Perilaku-Perilaku Sosial'. FOKUS: Jurnal Kajian Keislaman Dan Kemasyarakatan 3 (2): 171-98. https://doi.org/10.29240/jf.v3i2.667.

Salura, P. 2018. 'Anatomy of Architecture Based on the Creation of Space for Activity'. International Journal of Engineering and Technology(UAE) 7 (2.14): 205-7. https://doi.org/10.14419/ijet.v7i2.12.14675.

Salura, Purnama. 2001. Ber-Arsitektur; Membuat, Menggunakan, Mengalami, Memahami. Bandung: Architecture \& Communication.

- 2010. Arsitektur Yang Membodohkan. 1st ed. Bandung: CSS Publishing.

_. 2012. 'Sintesis Elemen Arsitektur Lokal Dengan Non Lokal, Studi Kasus: Gedung Sate Di Bandung, Gedung UPS Di Tegal'. Bandung.

- 2013. 'The Confusing Languange of Building Façades Observed along Ciumbuleuit Road in Bandung'. Journal of Language and Literature 4 (2): 101-5. https://doi.org/10.7813/j1l.2013/4-2/14.

. 2018. 'The Philosophy of Architectural Ordering Principles'. International Journal of Engineering and Technology (UAE) 7 (2.9): 
52-55.

https://doi.org/10.14419/ijet.v7i2.9.13346.

Salura, Purnama, and Stephanie Clarissa. 2018. 'Interpretation of the Meaning of Mosque Architecture: A Case Study Mosque 99 Cahaya in Lampung, Sumatera Island, Indonesia' International Journal of Engineering \& Technology 7 (2.2): 48. https://doi.org/10.14419/ijet.v7i2.2.12321.

Siswoyo, Suhandy, Nuryanto Nuryanto, and Riskha Mardiana. 2019. 'Arsitektur Masjid Sunan Gunung Jati Cirebon Sebagai Akulturasi Budaya Islam, Jawa, Dan Cina'. Jurnal Lingkungan Binaan Indonesia 8 (1): 56-63. https://doi.org/10.32315/jlbi.8.1.56.

Sopandi, Setiadi. 2009. 'Indonesian Architectural Culture during Guided Democracy (19591965): Sukarno and the Works of Friedrich Silaban'. In Dynamics of the Cold War in Asia.

https://doi.org/10.1057/9780230101999_4.

_. 2017. Friedrich Silaban. Jakarta: Gramedia Pustaka Utama.

Wijaya, Laely. 2008. 'Masjid Merah Panjunan Cirebon (Kajian Histori-Arkeologis)'.
Universitas Islam Negeri Sunan Kalijaga Yogyakarta. http://digilib.uinsuka.ac.id/1536/.

Znews. 2020. 'Masjid Merah Panjunan, Paduan Budaya Islam, China, Dan Hindu'. Znews.Id. 2020. https://znews.id/2020/05/01/masjidmerah-panjunan-paduan-budaya-islam-chinadan-hindu/\#: :text=Masjid Merah Panjunan ini telah,Hindu-Budha\%2C dan China.\&text=Dari gerbang\%2C tampak ciri khas bangunan mirip wihara atau klenteng.

\section{Author(s) contribution}

Arita contributed to the research concepts preparation, methodologies, investigations, data analysis, visualization, articles drafting and revisions.

Hartanto Budiyuwono contribute to methodology, supervision, and validation.

Yuswadi Saliya contribute to methodology, supervision, and validation. 
ARTEKS : Jurnal Teknik Arsitektur, Volume 6 Issue 2, August 2021

pISSN 2541-0598; eISSN 2541-1217 